\title{
Do International Students Appreciate Active Learning in Lectures?
}

\author{
Mauricio Marrone \\ Macquarie University \\ mauricio.marrone@mq.edu.au \\ Murray Taylor \\ Macquarie University \\ Mara Hammerle \\ Macquarie University
}

\section{Abstract}

Active learning has been linked with increased student motivation, engagement and understanding of course material. It promotes deep learning, helping to develop critical thinking and writing skills in students. Less well understood, however, are the responses of international students to active learning. Using social constructivist theory, the purpose of this study is to examine domestic and international student perceptions of active learning introduced into large undergraduate Accounting Information Systems lectures. Several active learning strategies were implemented over one semester and examined through the use of semi-structured interviews as well as pre- and post- implementation surveys. Our results suggest broad improvements for international students in student engagement and understanding of unit material when implementing active learning strategies. Other key implications include international student preference for active learning compared with passive learning styles, and that international students may receive greater benefits from active learning strategies than domestic students due to social factors. Based on these findings this paper proposes that educators should seek to implement active learning to better assist and integrate students of diverse backgrounds.

Keywords: active learning, lectures, international students, information systems, peer interaction, student engagement, collaborative learning

\section{Introduction}

The global demand for higher education is resulting in a rapid increase in the number of students desiring an international experience (Douglass and Edelstein 2015). Measured as the proportion of international students enrolled at tertiary education providers, Australia is among the countries with the highest levels of international students as a percentage of total tertiary enrolments, with approximately 17.5 percent in 2013 (OECD 2015). The higher education sector received 43.4 percent of all full-fee paying international students in Australia in 2015, with enrolments increasing by 9.1 percent and commencements increasing by 7.1 percent compared to 2014 (Australian Government Department of Education and Training 2015a). In 2015, education activity from international students living and studying in Australia contributed 18.2 billion Australian Dollars in exports, further contributing to the sustainability of its economy and universities (Australian Government Department of Education and Training 2015b).

Faced with unfamiliar cultural and educational concepts, international university students often lack social capital in their host country (Neri and Ville 2008). The unfamiliarity with teaching strategies common in Western cultures is considered to be a learning shock for international students and presents an educational barrier (Andrade2006; Huang 2012). The language barrier further limits international students from participating fully in the classroom learning environment (Kim 2011). These difficulties alongside the benefits of fostering international education experiences suggest that particular emphasis is placed on ensuring 
that international students are provided with the tools necessary for a successful integration into their new context.

Universities are considering different strategies to deal with the difficulties faced by diverse students in western classrooms and are increasingly moving towards more active learning strategies (Beetham and Sharpe 2013). A significant issue yet to be explored is how active learning impacts international students and their ability to learn in the host country. International students have been found to be challenged by foreign environments due to language and cultural differences (Andrade 2006; Huang 2012; Elliott and Reynolds 2014). International students often experience difficulties integrating into the new environment (Guo and Chase 2011), are challenged with new teaching styles (Rienties et al. 2012) and encounter problems with loneliness and isolation (Sawir et al. 2008). Research suggests that international students prefer to remain in familiar cultural and language groups rather than interacting or participating with domestic students (Eisenchlas and Trevaskes 2007; Dunne 2009; Montgomery 2009). Given these challenges, a call for research to help understand the impact of active learning on international students is warranted. Such research would assist in understanding the experiences of international students to ensure their needs are being met (Taylor et al. 2015) and present a way to deal with frustrations of students and staff concerning difficulties with actively engaging and encouraging international students to attend class (Ellis, Cummings, and Turner 2009).

This research aims to answer the research question, "How does active learning impact international students?" Given that active learning caters for a diverse range of learning styles, our study aims to understand how active learning strategies in large lectures impact international students. The paper's distinct contribution is a discussion of how international students benefit from a variety of active learning methods that emphasise group learning. The aims of this paper are to understand and compare theimpact of activelearning on international and domestic students (RQ1), to investigate how international and domestic students perceive active learning compared to more traditional passive lecturing styles (RQ2) and to understand if and how international students are impacted by an active learning strategy (RQ3). We discuss student perceptions ascertained from pre- and post- implementation surveys and indepth focus group interviews. We elaborate on the issue of the effectiveness of active learning regarding its ability to integrate international students. The following section discusses related work and our methodology. We then examine the findings from surveys and interviews, before we conclude the paper and provide an overview of future research.

\section{Literature Review}

Motivated by a desire to move away from the prevalent passive teaching style and involve students in learning, a number of studies assess the integration of active learning in classroom environments (Córdoba and Piki 2012; Wu and Sankar 2013; Tan, Satin, and Lubwama 2013). Active learning is described as incorporating strategies that involve students in their learning processes to keep them engaged (Prince 2004). Active learning not only involves engaging with activities, students must also reflect, analyse, evaluate and communicate information (Fink 2013). In comparison to "passive learning" methods whereby the teacher is responsible for instruction, active learning is student-centred and inductive (Smith and Cardaciotto 2011).

Active learning has been found to assist in the creation of learning environments that engage, inspire and motivate business students to learn both the unit material and the soft skills required for their future careers (Auster and Wylie2006; Richards and Marrone 2014). Several active learning studies have also focused on the benefits of collaborative learning. Cooperation may develop interpersonal relationships, strengthen social supports and improve self-esteem (Prince 2004). The social constructivist theory has been used by studies to underpin collaborative learning experiences (Cooperstein and Kocevar-Weidinger 2004; Woo and Reeves 2007; Schreiber and Valle 2013). This theory places the emphasis on the construction of knowledge by the learner, arguing that an individual's knowledge is produced through the process of negotiating meanings with others (Savin-Baden and Major 2004). Au (1998) argues 
that a learner's cognitive development further depends on social interactions with more advanced and knowledgeable individuals. While engaging with peers and experts, learners generate ideas, negotiate, synthesise individual and group thinking processes, and refine tasks based on sharing insights and perspectives (Woo and Reeves 2007). Collaborative learning activities based on social constructivism offer learners opportunities to experience perspectives of students from diverse backgrounds and to develop critical thinking skills through assessing different viewpoints (Stacey 2007). In contrast to students working individually, social interaction enables increased discussion, enthusiasm, participation and experimentation. Students are resultantly more relaxed, confident and likely to share opinions (Cooperstein and Kocevar-Weidinger 2004).

In response to the limitations of passive lecture formats, instructors have employed the use of multiple active learning strategies. Studies have examined collaborative learning (Opdecam and Everaert 2012; Brickner and Etter 2008; Cavanagh 2011) various games and simulations (Fowler 2006; Bentley, Brewer, and Eaton 2009) and mobile learning (Murphy et al. 2014). Research has found that social interaction is important for an individual's cognitive ability development (Carroll and Ryan 2007). Peer interaction may also provide learners with heightened belonging, which can positively impact student retention rates and learning outcomes (Eames and Stewart 2008; Huijser, Kimmins, and Evans 2008). The possibility for students to discuss their interpretations with their peers exposes them to a wider diversity of perspectives than their teacher can provide (Liu and Carless 2006), which is particularly important in large classrooms where timely feedback from instructors is difficult (Rubin 2006). Other studies have examined the use of interactive student response systems (Carnaghan and Webb 2007; Edmonds and Edmonds 2008; Blasco-Arcas et al. 2013). This strategy offers a solution that is logistically practical for large lectures, offering a method of increasing students' metacognitive awareness and engagement levels (Hall et al. 2005; Pye et al. 2015) but it prevents increased social interaction among students, a common issue faced by traditional lectures (Pohl, Gehlen-Baum, and Bry 2011).

In business education, a review of 85 articles on active learning literature has shown that the most frequently occurring outcomes of introducing active learning were understanding of course material, student engagement and real-world understanding with the majority of the research carried out at the undergraduate level (Marrone et al. 2016). Previous research in the field of Information Systems have indicated the positive impacts of active learning in a faceto-face environment on students, including an improvement in student satisfaction (Wu and Sankar, 2013), motivation and engagement (Córdoba and Piki, 2012), social interactions (Abrahams and Singh, 2013), and on student academic performance (Halttunen, 2005; Riley and Ward, 2015). Together, these studies highlight the positive impact that active learning has on students.

However, the literature tells us little about the impact of active learning on international students, an increasingly predominant sector of universities worldwide (Kelly and Moogan 2012). International students face a range of issues in adapting to a new lifestyle and culture including differences in learning styles, culture shock, homesickness and social difficulties (Sawir 2005). Problems with English language proficiency have also been found to be a persistent challenge for international students in new learning environments (Andrade 2006; Kim 2011). Studies have found that the language barrier limits the abilities of international students to convey their thoughts in English and to complete classroom tasks (Sawir 2005; Kim 2011). Alongside a perceived preference to remain in familiar cultural and language groups (Eisenchlas and Trevaskes 2007), limited English language ability creates obstacles for interaction with domestic students (Arkoudis et al. 2013). Assessment tasks common in western countries, including group discussion and classroom presentations, may additionally be unfamiliar to international students, further limiting their ability to become fully engaged with their peers (Kim 2011). Thus, the silence typically associated with international students in classroom environments may also be linked to their perceptions of being useless in group discussions and beliefs that domestic students perceive them to be deficient in some way (Hsieh 2007). 


\section{Case Setting}

Haar et al. (2002) argue that the ability to teach to the needs of learners with different learning styles has become increasingly important as student populations have diversified. As such, a number of active learning strategies were incorporated into a second-year undergraduate accounting information systems unit at a Australian metropolitan university over the Session 12015 teaching period. Consistent with the social constructivist theory, the integration of weekly in-class discussions and collaborative activities focused on simulating real-world concepts with direct links to the unit material sought to increase student participation and interaction. Student engagement and motivation were also addressed by collecting the names of those students who asked and answered questions during large group discussions in anticipation of a raffle held at the end with a prize relevant to that week's topic. As an example, the prize offered in the lecture dedicated to the revenue cycle was a package of chocolate coins. Rewards are widely viewed as effective, motivating students to expend effort and to encourage their intrinsic interest in an activity (Brophy 2013). Socrative, a student response system, was also used intermittently to enable the lecturer to test critical thinking questions, formal assessment checkpoints and understanding of the content material (Blood et al. 2008). Before answering the questions in Socrative, students were asked to pair up and discuss their answers. These activities stressed the importance of collaborative learning in both small and large groups. In tutorials, a problem-based learning approach was followed.

\section{Research Approach}

Through a mixed-method approach, incorporating both pre- and post- surveys and semistructured interviews, student perceptions concerning the implementation of these active learning strategies were examined. Student responses from both Session 2 2014, before the implementation of the learning strategies, and Session 12015, in which the learning strategies were integrated, were recorded with the aim of better understanding changes in student perceptions. In accordance with Yin (2013), a case study design based on a mixed method approach was adopted, allowing for an increased depth of data to be obtained. Through complementing quantitative methods with qualitative, case study-based research, we enhance the validation of the research findings (Modell 2005). The questions posed in the Likert surveys were based on a question bank provided by the university. The interviews aimed to further develop the findings from the surveys.

\subsection{Surveys}

Survey research offers many advantages, including versatility, simplicity and speed and when performed correctly, can provide an accurate and efficient overview of a target population (J ohnson, Bristow, and Schneider 2011). The survey was distributed to lectures of the unit in Session 12014 and Session 22015.

Social constructivist theory suggests that students can gain a deepened understanding of the material by peer learning and being exposed to a wide variety of perceptions (Vygotsky 1980). Collaborative learning may be linked to such learning outcomes as increased student engagement, opportunities to assist learning (Chad 2012), a more positive course experience and developed teamwork skills (Reinig, Horowitz, and Whittenburg 2011). Learners become active in the process of knowledge acquisition as they participate in discussions and co-create knowledge through exchanging perspectives with other students (Brindley, Blaschke, and Walti 2009). Hence, we chose questions from the end of session learning and teaching survey that most closely aligned with these factors.

In addition to demographical aspects, questions included:

[CRT01] This teacher communicated well with the class.

[CRT02] This teacher seemed enthusiastic about teaching the class.

[CRT03] This teacher created a good environment for learning. 
[CRT04] This teacher used methods and techniques that were effective in helping me learn.

[CRT05] This teacher showed genuine interest in assisting students' learning.

[ENT01] This teacher motivated me to learn.

[ENT02] This teacher used a style of presentation that held my interest.

[ENT03] This teacher encouraged students to learn more about the ideas presented.

[ENT04] This teacher encouraged students to participate in class.

[GCU01] This unit enhanced my ability to think creatively.

Each question was coded for easier analysis. Two hundred and twenty-two students participated in the pre- survey whereas 191 students responded to the post- survey, forming a total of 413 students. A high proportion of students involved in the surveys were international students and spoke a language other than English as their first language. They were also required to take the unit as a compulsory component of their degree program. There were slightly more males involved in the pre- survey as compared to females in the post- survey however this difference was not large. Although the second cohort was not comprised of the same students, their demographic similarity and a large number of students surveyed enabled comparisons to be made. Table 1 highlights the breakdown of students according to gender and student status.

\begin{tabular}{|l|r|r|r|r|r|r|}
\hline & \multicolumn{3}{|l|}{ Gender } & \multicolumn{2}{l|}{ Nationality } \\
\cline { 2 - 7 } & Male & Female & N/A & International & Domestic & N/A \\
\hline Pre & 92 & 98 & 32 & 105 & 94 & 19 \\
\hline Post & 71 & 107 & 13 & 101 & 60 & 29 \\
\hline Pre (\%) & $41 \%$ & $44 \%$ & $14 \%$ & $48 \%$ & $43 \%$ & $9 \%$ \\
\hline Post (\%) & $37 \%$ & $56 \%$ & $7 \%$ & $54 \%$ & $31 \%$ & $15 \%$ \\
\hline
\end{tabular}

Table 1: Demographic details of survey participants

\subsection{Interviews}

By securing rich descriptions and capturing the individual's point of view, qualitative research is distinct from quantitative research methodologies (Yin, 2013). Semi-structured interviews are accessible, flexible and capable of uncovering important and often undisclosed aspects of human behaviour that surveys are not able to reveal (Qu and Dumay 2011).

In the final weeks of Session 12015 , semi-structured interviews were conducted with student volunteers enrolled in the unit, contributing to the data obtained from the surveys. Students were recruited by a research assistant and received gift cards for their participation. To minimise bias, the research assistant was not involved in teaching the unit.

The interviews were held in focus groups. Focus groups enabled participants to respond to questions and prompts by the interviewer and other participants. As the active learning approach was collaborative and often required the group interaction of students, the use of focus groups is justified and considered extremely useful for studying the impact of individual's interactions (Belanger, 2012). The interviews sought to address how students perceived the learning environment in the active learning classroom as compared to their other units and whether any challenges were faced with the aim of improving future offerings of the unit. Each focus group had a maximum of four students and involved the posing of open-ended questions.

Open-ended questions were used to gain participants attitudes and opinions while simultaneously avoiding biasing respondents towards specific issues that the researchers deemed more important (Belanger, 2012). The final number of participants interviewed was 
12 with four focus groups being conducted. Examination of a higher number of participants or focus groups was not necessary as the four focus groups offered rich data and provided opportunities for cross-case analysis. Strauss and Corbin (1990, p.188) state that researchers should collect data until "no new or relevant data seem to emerge". After the final focus group increasing interview data was deemed unnecessary as the twelve interview participants across four focus groups represented the point of theoretical saturation.

Of the twelve participants, nine were female and three were male, three were classified as international students while the remaining nine were domestic students. The students were split into four focus groups. The participants in each focus group were divided to create a more balanced sample however one focus group was comprised of two female students whileanother focus group had only domestic students.

\subsection{Analysis}

The data collected in the surveys was number-coded using a Likert scale with 1 being the lowest possible score and 5 being the highest possible score. Likert surveys are well-known, can be used to obtain data from a large number of respondents and enable statistical generalisation (Eyvindson et al. 2014). The mean for each outcome was calculated separately before a oneway ANOVA test was used to identify statistical significance. One-way ANOVAs have previously been used by scholars to compare group differences in such aspects as learner satisfaction, learning achievements and participation (J ung et al. 2002), perceived cognitive learning (Rovai and Barnum 2007) and memorisation (Cherney 2008).

The interviews were transcribed and analysed using both manual and software analysis to help avoid possible interpretation errors (Flick, 2008). Based on over four hours of interview data more than 24,000 words were transcribed. Initially, each interview transcript was manually coded by the researchers. As qualitative data is textual, unstructured and non-numerical, this process allowed for the emerging phenomena to be coherently compressed (Basit 2003). This helped the researchers gain insight into the data as well as control over the analytical process. By examining the interview data, the researchers were able to conceptualise key themes and commonalities both within and between focus groups. This helped extract overall impressions and tentative themes. To help further sort, organise, store and manage the large quantities of data involved in the study NVivo software was adopted. Although the use of the specialised qualitative software was implemented, it does not replace the researcher or their role in the analysis or interpretation of data (Morse et al., 2008). To categorise themes more easily, the research questions were referred to as part of the coding process. NVivo was found to be a useful tool for linking the data with emerging concepts and themes. To aid in the transparency of findings, illustrative quotes from focus group participants are used to emphasise key themes or issues that emerged from manual and software analysis (Pratt 2008, 2009). For each illustrative quote, the participant is provided a pseudonym so that they may remain anonymous.

\section{Findings}

This section commences by seeking to understand how active learning is perceived by both international and domestic students. First, we present the survey results, comparing the impact on these student cohorts before and after the active learning strategies were implemented (RQ1). Following this, the interview data from focus groups is presented to highlight how international and domestic students perceive active and passive learning strategies (RQ2). Finally, the paper will seek to address the impact of active learning on international students (RQ3).

\subsection{Overall findings from surveys}

RQ1: The impact of active learning on international and domestic students

To assess the impact of active learning on both international and domestic students (RQ1), one-way ANOVAs and an analysis of means were used to analyse the pre- and post- 
implementation survey data. The overall means are presented in Figure 1 and highlights an increase in mean across all aspects assessed. Additionally, Figure 2 shows that the standard deviations for all outcomes decreased in the second survey, indicating that the active learning strategies lead to overall higher mean scores with lower variability.

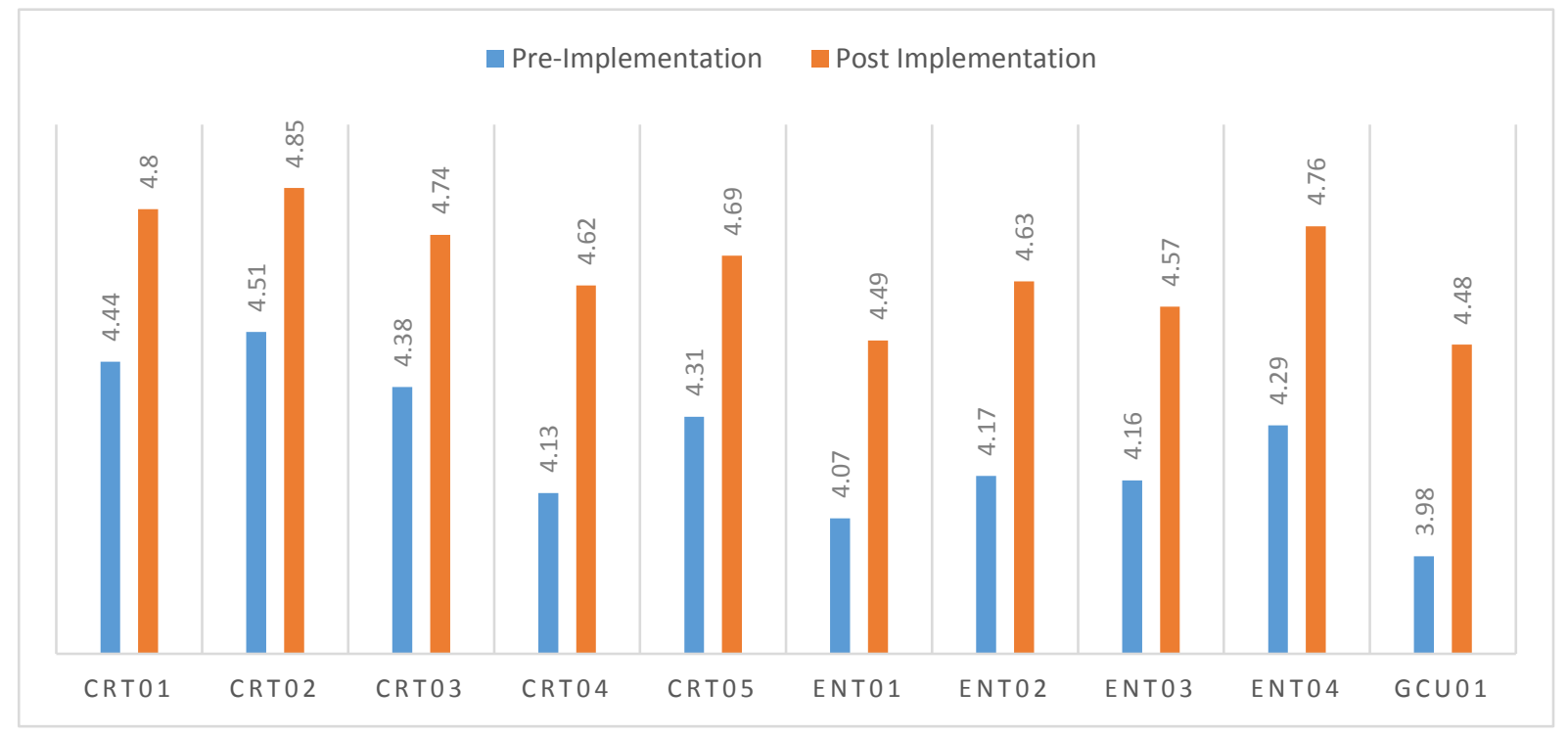

Figure 1: Means for survey outcomes

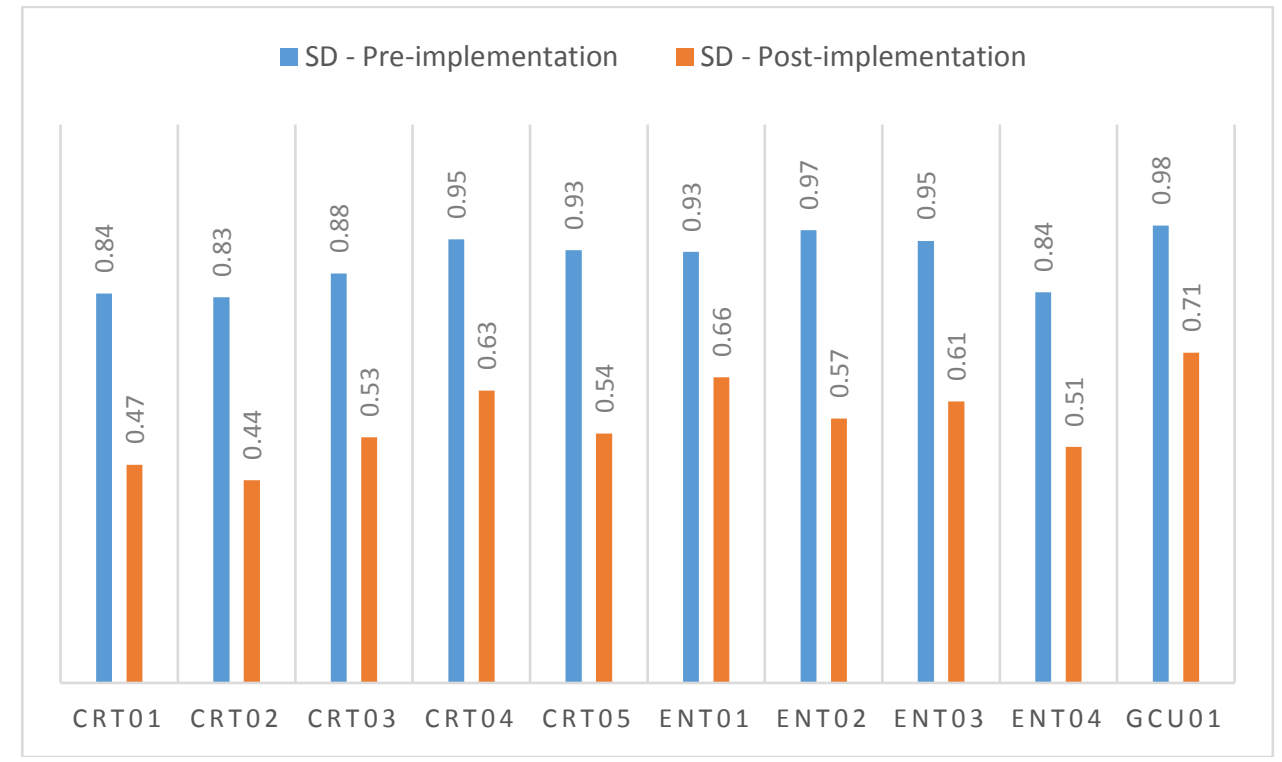

Figure 2: Standard Deviation (SD) for survey outcomes

As highlighted by Table2, there was a statistically significant difference between pre- and postimplementation groups as determined by one-way ANOVAs for all ten outcomes examined, suggesting that the introduction of active learning was associated with improvements in all aspects investigated. The size of the effect ( $\mathrm{r}$ ) was calculated for all appropriate analyses. 


\begin{tabular}{|llcc|}
\hline \multicolumn{1}{c}{ Outcome } & \multicolumn{1}{c}{ F } & p & r \\
\hline $\begin{array}{l}\text { [CRT01] This teacher communicated well with the } \\
\text { class }\end{array}$ & $\mathrm{F}(1,378)=24.937$ & 0.001 & 0.25 \\
\hline $\begin{array}{l}\text { [CRT02] This teacher seemed enthusiastic about } \\
\text { teaching the class. }\end{array}$ & $\mathrm{F}(1,375)=22.077$ & 0.001 & 0.24 \\
\hline $\begin{array}{l}\text { [CRT03] This teacher created a good environment } \\
\text { for learning }\end{array}$ & $\mathrm{F}(1,382)=22.333$ & 0.001 & 0.24 \\
\hline $\begin{array}{l}\text { [CRT04] This teacher used methods and techniques } \\
\text { that were effective in helping me learn }\end{array}$ & $\mathrm{F}(1,381)=32.06$ & 0.001 & 0.28 \\
\hline $\begin{array}{l}\text { [CRT05] This teacher showed genuine interest in } \\
\text { assisting students' learning }\end{array}$ & $\mathrm{F}(1,373)=22.241$ & 0.001 & 0.24 \\
\hline [ENT01] This teacher motivated me to learn. & $\mathrm{F}(1,378)=23.979$ & 0.001 & 0.24 \\
\hline $\begin{array}{l}\text { [ENT02] This teacher used a style of presentation } \\
\text { that held my interest. }\end{array}$ & $\mathrm{F}(1,367)=28.211$ & 0.001 & 0.27 \\
\hline $\begin{array}{l}\text { [ENT03] This teacher encouraged students to learn } \\
\text { more about the ideas presented. }\end{array}$ & $\mathrm{F}(1,378)=23.658$ & 0.001 & 0.24 \\
\hline $\begin{array}{l}\text { [ENT04] This teacher encouraged students to } \\
\text { participate in class. }\end{array}$ & $\mathrm{F}(1,380)=39.386$ & 0.001 & 0.25 \\
\hline $\begin{array}{l}\text { [GCU01] This unit enhanced my ability to think } \\
\text { creatively }\end{array}$ & $\mathrm{F}(1,371)=30.191$ & 0.001 & 0.27 \\
\hline
\end{tabular}

Table 2: Statistical significance of improvements in survey outcomes

The results suggest that active learning strategies can positively affect student perceptions of thelecture. Specifically, our results suggest that when activelearning is introduced into a large lecture hall, students may perceive improvements in the lecturer's communication skills, enthusiasm and interest in assisting student's learning and will benefit from the creation of a good learning environment and the use of effective learning techniques. The students reported higher motivation to learn, participate, think creatively and remain interested in the unit material.

\subsection{Survey perceptions of international students concerning active learning}

In the following, we compare how international and domestic students perceived the active learning introduced into the Accounting Information Systems lectures (RQ1). A comparison of means is provided in Figure 3. Similarly, for international students, the means for all aspects assessed increased, suggesting that improvements in all areas examined by the surveys were noted. In comparison, the differences between means (pre and post) for international students tended to be higher than for domestic students in both surveys, indicating that international students may perceive a greater positive impact on active learning than domestic students. 


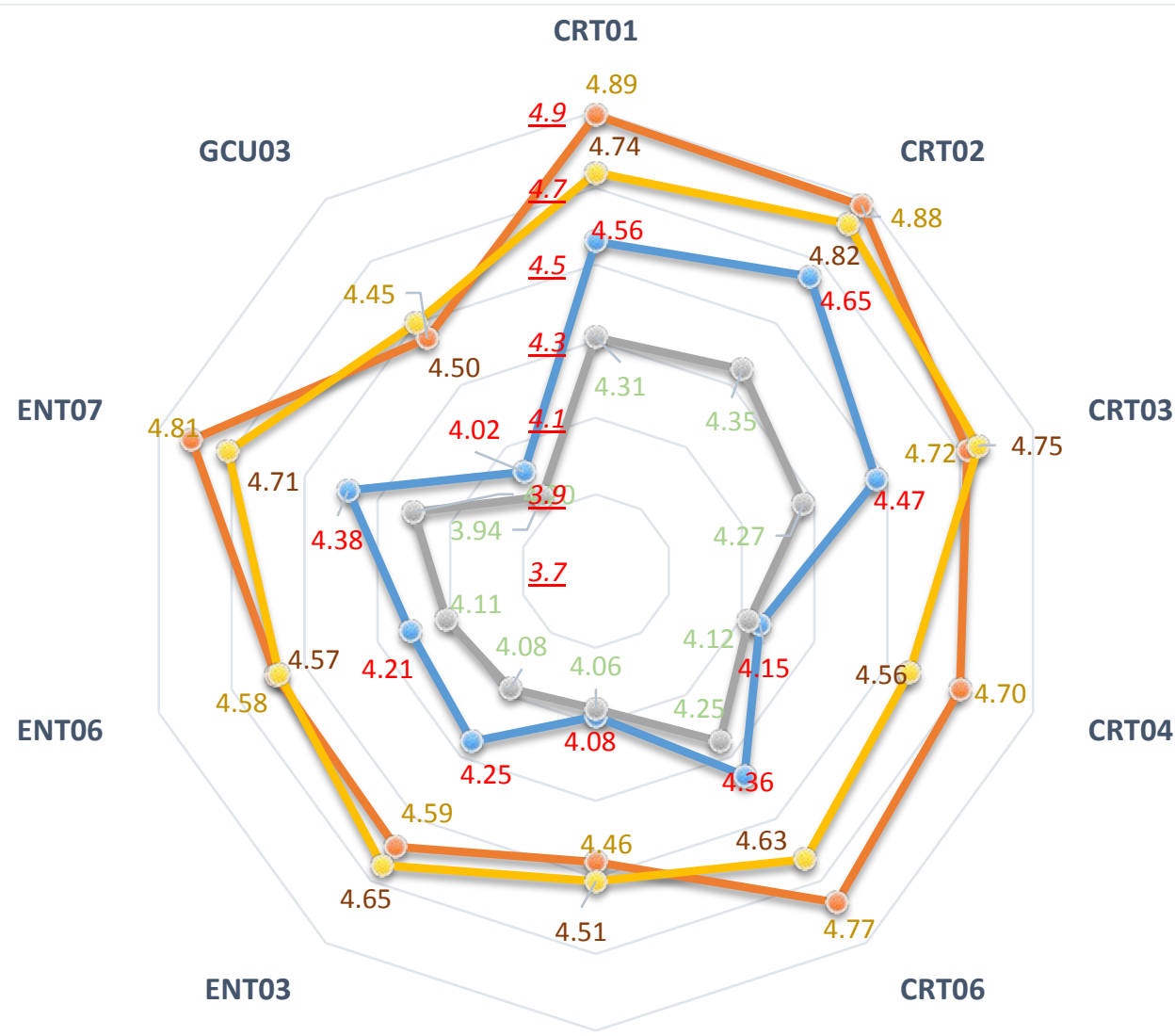

ENT02

$$
\begin{aligned}
& -\infty-\text { Domestic Pre } \quad-\text { Domestic Post } \\
& -0-\text { International Pre }=- \text { International Post }
\end{aligned}
$$

Figure 3: Comparison of the means for international and domestic students for survey outcomes

A one-way ANOVA was calculated of international students' perception of their learning experience beforeand after theintroduction of activelearning. The analysis presented in Table 3 highlights that the improvements in all ten variables analysed were statistically significant. 


\begin{tabular}{|c|c|c|}
\hline $\mathbf{F}$ & P & $\mathbf{r}$ \\
\hline $\begin{array}{l}\text { [CRT01] This teacher communicated well with the } F(1,193)=20.484 \\
\text { class. }\end{array}$ & 0.001 & 0.31 \\
\hline $\begin{array}{l}\text { [CRT02] This teacher seemed enthusiastic about } F(1,193)=24.492 \\
\text { teaching the class. }\end{array}$ & 0.001 & 0.34 \\
\hline $\begin{array}{l}\text { [CRT03] This teacher created a good environment for } F(1,200)=22.597 \\
\text { learning. }\end{array}$ & 0.001 & 0.32 \\
\hline $\begin{array}{l}\text { [CRT04] This teacher used methods and techniques } F(1,196)=15.179 \\
\text { that were effective in helping me learn. }\end{array}$ & 0.001 & 0.27 \\
\hline $\begin{array}{l}\text { [CRT05] This teacher showed genuine interest in } \mathrm{F}(1,196)=13.991 \\
\text { assisting students' learning. }\end{array}$ & 0.001 & 0.26 \\
\hline [ENT01] This teacher motivated me to learn. & 0.001 & 0.28 \\
\hline $\begin{array}{l}\text { [ENT02] This teacher used a style of presentation that } F(1,190)=29.386 \\
\text { held my interest. }\end{array}$ & 0.001 & 0.30 \\
\hline $\begin{array}{l}\text { [ENT03] This teacher encouraged students to learn } \mathrm{F}(1,196)=18.813 \\
\text { more about the ideas presented. }\end{array}$ & 0.001 & 0.30 \\
\hline $\begin{array}{l}\text { [ENT04] This teacher encouraged students to } F(1,197)=27.771 \\
\text { participate in class. }\end{array}$ & 0.001 & 0.35 \\
\hline $\begin{array}{l}\text { [GCU01] This unit enhanced my ability to think } \mathrm{F}(1,193)=2 \\
\text { creatively. }\end{array}$ & 0.001 & 0.32 \\
\hline
\end{tabular}

Table 3: Statistical significance of improvements in survey outcomes for international students

Our results suggest that incorporating active learning into the classroom has a greater impact on international students than domestic students. International students may appreciate being immersed in an active learning environment to a greater extent than domestic students. In the interviews, international students tended to report outcomes that could beclosely linked to the statements "this teacher encouraged students to participate in class" and "this teacher created a good environment for learning." As can be observed from Table 3, these outcomes were amongst those that experienced the most significant improvements.

\subsection{Focus group perceptions from international and domestic interviewees comparing active and passive learning}

RQ2: How international and domestic students perceive active learning compared with passive lecturing styles

Our findings suggest that both international and domestic students had similar perceptions of learning styles, with participants highlighting the benefits of active learning over a more passive approach. A key outcome of the interviews was the emphasis on increased levels of student engagement due to active learning. Both domestic and international students found that the introduction of activities into the lecture improved student engagement, comparing this with passive lectures in which students are commonly disengaged. According to Elias:

'It was actually very engaging because usually in other lectures, there's just a lot of passive, just sitting down, just listening. But this one was good because you engaged more with the lecture."

Students reinforced the notion that engaging and active lectures better-supported student learning. Passive lectures do not encourage student engagement whereas active lectures provide students with greater opportunity to respond, encouraging students to discuss the unit material and reprocess what has been taught. Another student, Ruby, echoes this sentiment, suggesting that the teaching materials in the active learning lectures help students to understand more. 
"Like in my lecture, she [the lecturer] just gets the slides and finish and go earlier. But that [active learning] lecturer, he keeps more activities and slides, so we can actually know what he's trying to explain."

Another significant comparison between active and passive lectures mentioned by both domestic and international students was the possibility to make friends and feel a sense of connection. According to both groups, there is little possibility to interact with the students seated nearby in passive lectures due to the focus placed on listening to the teaching staff. In comparison, the students of this study felt they were able to chat and get to know other students in the active lectures due to the integration of collaborative activities. The integration of group work in applying theory to practice exposed students to a wide variety of different perspectives, questioning their notion of the truth. According to Mark:
"There was an activity where we had to describe the methods that we use to make tea. That was to demonstrate that not everyone develops the system in the same way... I was able to see that some people developed tea without using milk [laughter], some people think that it should be used with milk like me [laughter]. So people have different cultural backgrounds and different perspectives of the way we do things."

The benefits associated with the active learning strategies resulted in both domestic and international students feeling more motivated to attend lectures. A number of students reported that they feel unmotivated to attend lectures in which there is little opportunity to ask questions or interact. Selina perceives studying at home to be more beneficial when she is unable to understand the content of passivelectures. In comparison, the active lectures helped her to better understand greater amounts of content in a shorter amount of time:

"Sometimes I feel that with the other lectures... if you don't understand it, you don't feel motivated to come. It just seems like I can study at home and understand it better. But these lectures I feel, really do help me understand the work, and I don't have to put so much effort when I go home".

\subsection{Focus group perceptions from international interviewees discussing benefits of active learning}

RQ3: How are international students impacted by an active learning strategy

In this section, we aim to explore why active learning was particularly effective for international students. We focus on key themes that emerged from the interview data. Overall international student perceptions of active learning approaches during lectures are positive suggesting that international students perceive active learning to be highly beneficial.

A key theme that emerged from focus groups was that international students felt active learning strategies assisted them in understanding the course content. Students reported that the activities helped to make intangible concepts more comprehensible and easy to understand. By focusing on examples after introducing theory, active learning can improve students' ability to apply difficult theoretical concepts. For Ruby, the tea activity, in which students were instructed to write a procedure for brewing tea, helped her understand how the same task can be achieved in a number of equally beneficial ways. Active learning activities such as the tea activity help students to understand the different processes that organisations have, thereby helping a topic that was intangible and difficult to understand become comprehensible. This highlights the importance of using examples that students are familiar with to guide their comprehension. As Ruby highlights:

"So that shows a difference and then we know that different people will have different processes to do one thing. So different organisations will have [different] process for what they're doing."

The active learning strategies for the international student interviewees provided exposure to a wide variety of different perspectives through collaborative learning. Several interviewees placed an emphasis on the benefits of student interaction, stressing their satisfaction in being 
able to understand a concept from another student's point of view. Student interaction was a critical aspect of this as it forced students to engage with others and resulted in a broader understanding of the different ways in which a topic can be approached and understood. According to Laurice:

"When you interact with people, you always get good ideas. And they also help you more to understand that topic." [SIC]

Through the collaborative learning activities, students are encouraged to interact with a number of students. This contrasts with the traditional lecture where there is limited opportunity for students to discuss the topic and form their own meanings and interpretations. This aspect was particularly prominent for Wonder:

"Someone's sitting next to you in a lecture, because everyone's listening to the lecturer and that's all, after two hours, "Okay, we're done, just leave." But he asks us to talk in pairs and discuss the questions."

These factors helped to ensure an environment in which international students felt safe to participate in class discussions. For Laurice, the emphasis placed by the lecturer on asking questions and providing encouragement helped her to feel more comfortable to interact. This sentiment was also echoed by other interviewees who felt that the active learning strategies helped to promote more class participation than passive learning lectures. Students can often find it difficult to express themselves in front of large groups of people due to fear of being laughed at. The active learning environment ensured that they felt comfortable in discussions. As Laurice emphases;

'But like more than 30 students, I'm still feeling nervous. But I think in thelecture, it's okay. Even if I give the wrong answer, no one will laugh at you or something. It's just a very fair discussion, like a huge group discussion."

Another key theme that emerged was the number and quality of peer interactions that international students experienced because of an active learning approach. This helped them achieve a sense of belonging and friendship. The ability to make friends is a beneficial aspect of the active learning strategies implemented. A recurrent theme in theinterviews was a desire amongst interviewees to be involved and be a part of the community nurtured in the active learning classroom. The collaborativelearning activities can be particularly helpful in ensuring belonging due to the potential for making friends through interactions enforced through the activities. As Ruby discusses;

"I think I have a sense of belonging because we have to discuss one question with the one sitting next to me all the time... We can make friends every lecture, like the one sitting next to me. I think that's good."

\section{Discussion}

The present study was designed to investigate how and why international and domestic students perceive and are impacted by active learning strategies within lectures. The first research question in this study sought to determine the impact of active learning on both international and domestic students. Our results indicate that both international and domestic participants perceived that the active learning strategies implemented increased their understanding, satisfaction with the unit and desire to participate, thus strengthening their ability to progress through the course. Our results show the benefits of active learning in addressing a wide range of concerns, ensuring that students feel comfortable to express themselves and enhancing their learning opportunities. In a context in which lectures can be described as depersonalised experiences (Smith and Cardaciotto 2011), these contributions are particularly noteworthy.

The study also set out to investigate how international and domestic students perceive active learning to differ from more traditional passive lecturing styles. Our findings highlight that international and domestic students were found to appreciate the opportunity to explore new 
ways of learning, enabling them to more readily express their viewpoints and participate in class discussions. In the case of international students, previous studies indicate that typically Asian students participate less in group discussions or debate in class and are less keen to ask or answer questions (Duanmu, Li, and Chen 2009). International students may face difficulties in adjusting to a new learning style (J ackson 2003) given the emphasis placed on alternate learning styles in different educational paradigms (Hawthorne, Minas, and Singh 2004; Wong 2004). Our findings for international students, however, indicate an increased motivation to participate and motivation to learn. Increases in engagement and participation were indicated by both the surveys and interviews. International students indicated that a good environment for learning was created and that they were able to benefit from the focus on active learning and collaborative activities. Similar to the findings of Chalmers and Volet (1997), these results challenge university educators to reconsider their views of international students being surface learners who are passive and non-participatory in class.

Finally, we explore why international students are impacted by an active learning strategy. Results show that the exposure of students to different perspectives helped them to form a deeper understanding of the unit material as their perceptions were shaped by the knowledge and experiences of their peers. The comments made by the interviewees resemble the positions articulated by the social constructivist theory; that knowledge is co-constructed through working cooperatively with peers. Through peer interaction, beliefs were challenged, and the effects of cultural backgrounds on the students' initial perceptions were made apparent. In this process, students gained an increased sense of belonging and inclusion. These findings contrast those of other studies, which have found that international students tend to feel alienated and isolated, resulting in undermined confidence, reduced motivation, decreased participation and withdrawal from learning opportunities (Treloar et al. 2000; Hawthorne, Minas, and Singh 2004). Instead, our study highlights that the exposure of a multicultural cohort to active learning may benefit students in a number of ways, including by enhancing opportunities for peer interaction and belonging. This understanding is particularly important as positive changes in self-perceptions including scholastic competence, self-worth, and likelihood to complete college degrees are linked with improved social networks (Pittman and Richmond 2008; Wilson and Gore 2013). Campbell and Li's (2007) research found that group work could provide international students with opportunities to improve their English language skills, enhance their cultural understandings and develop their teamwork, interpersonal communication and negotiation skills. This study builds on this and highlights that when collaborative learning tasks require different skills and approaches to complex problems, placing students in culturally heterogeneous groups can result in more advanced learning outcomes.

Overall, the study's findings highlight the need for educators to design the learning approach such that students can participate and express their viewpoints. We conclude that breaking large student cohorts into small groups may be especially beneficial for international students as they feel more comfortable and have a greater motivation to learn. As indicated by our study, students can brainstorm ideas in a smaller, safer social environment and are more confident in expressing their views to a larger audience. Taken together, these findings emphasise the importance of transitioning from passive learning modes to a more active and cohesive approach. The findings of this study highlight that the introduction of active learning may assist in improving the tertiary learning experience providing important insights for other university educators.

Results of this study are inherently limited. The preliminary results of this study represent only a small sample of the student cohort enrolled in this unit over the two semesters. Thus, the results from the self-selected small sample of students included in the interviews may not be reflective of the broader population. Furthermore, while the survey and focus group questions focused on the lecture, tasks completed in tutorials may also affect the perception of students. Further qualitative research examining larger groups of international students would be beneficial. This study also focused solely on an Australian context. As results may differ between contexts, similar studies in other countries with different cohorts are needed to 
support our findings. Nevertheless, our study reports findings from an important yet underresearched study area. We provide support for the use of active learning in large lectures with diverse student cohorts, using a wider range of strategies to support student learning than in previous studies in this area. We place greater emphasis on differentiating between the perceptions of international and domestic students and are the first that we know of to report on the reasons why international students may benefit from active learning. Importantly our findings show that international students may benefit from active learning strategies to a greater extent than domestic students.

This research represents a step forward in our understanding of the benefits of active learning strategies for both domestic and international students. However, future research should continue to seek to understand which obstacles active learning can assist in overcoming. A large body of literature suggests that international students must cope with a number of different obstacles when compared with domestic students. Common obstacles mentioned in the literature include difficulties to socially integrate into the host country (Rienties et al. 2012), academic perceptions of international students' English language ability (Arkoudis et al. 2013) and feelings of homesickness (Baba and Hosoda 2014). Future research might also seek to address the academic culture shock experienced by international students and how active learning might help in this area. The opinions of lecturers and teaching staff on how they perceive active learning rather than passive teaching approaches to benefit international students would also be a prudent topic of research. This would aid in the understanding of teaching strategies for international students and inform future policy so that the demands and needs of teaching staff are also met.

\section{Conclusion}

This research aims at obtaining survey and interview data concerning the perceptions of international and domestic students towards active learning in lectures in an undergraduate accounting information systems course. The findings of this research clearly highlight that active learning is perceived positively by both student groups, improving student attitudes towards the course and teaching staff, engagement and participation. International students, in particular, benefited from this learning strategy with its emphasis on integration and participation in weekly lectures. Active learning provided students with an environment in which they felt safe, supporting peer interaction and a heightened ability to apply and understand theoretical concepts. Furthermore, our findings indicate that social constructivist theory assists with better understanding the complexities inherent in collaborative learning. Students were exposed to a wide variety of perspectives rather than merely the lecturer's view, helping them to shape and reshape their thoughts and perspectives. Students learnt from each other and were involved in the co-construction of knowledge. This study can aid in the development of institutional planning by providing key insights into the ways that active learning may benefit both domestic and international students.

\section{References}

Abrahams, Alan S., and Tirna Singh. (2013). “Expeditionary Learning in Information Systems: Definition, Implementation, and Assessment." Decision Sciences J ournal of Innovative Education 11(1): 47- 75. doi:10.1111/j.1540-4609.2012.00369.x.

Andrade, Maureen S. (2006). "International Students in English-Speaking Universities." Journal of Research in International Education 5 (2): 131-54. doi:10.1177/ 1475240906065589.

Arkoudis, Sophie, Kim Watty, Chi Baik, Xin Yu, Helen Borland, Shanton Chang, Ian Lang, J osephine Lang, and Amanda Pearce. (2013). "Finding Common Ground: Enhancing Interaction between Domestic and International Students in Higher Education." Teaching in Higher Education 18 (3): 222- 35. doi:10.1080/ 13562517.2012.719156. 
Au, Kathryn H. (1998). "Social Constructivism and the School Literacy Learning of Students of Diverse Backgrounds." Journal of Literacy Research 30 (2): 297-319. doi:10.1080/ 10862969809548000.

Auster, Ellen R., and Krista K. Wylie. (2006). "Creating Active Learning in the Classroom: A Systematic Approach." Journal of Management Education 30 (2): 333-53. doi:10.1177/ 1052562905283346.

Authors, 2016.

Australian Government Department of Education and Training. (2015a). "Export Income to Australia from International Education Activity in 2014-15." https:/ / internationaleducation.gov.au/research/ Research-

Snapshots/ Documents/ Export\%20Income\%20FY2014-5.pdf.

2015b. "Monthly Summary on International Student Enrolment Data- Australia- YTD October (2015)." https:// internationaleducation.gov.au/research/InternationalStudent-

Data/ Documents/ Monthly\%20summaries\%20of\%20international\%20student\%20enr olment\%20data\%202015/10_October_2015_MonthlySummary.pdf.

Baba, Yoko, and Megumi Hosoda. (2014). "Home Away Home: Better Understanding of the Role of Social Support in Predicting Cross-Cultural Adjustment among International Students." College Student J ournal 48 (1): 1.

Basit, Tehmina. (2003). "Manual or Electronic? The Role of Coding in Qualitative Data Analysis." Educational Research 45 (2): 143- 54. doi:10.1080/0013188032000133548.

Beetham, Helen, and Rhona Sharpe. (2013). Rethinking Pedagogy for a Digital Age: Designing for 21st Century Learning. Routledge.

Belanger, France. (2012). "Theorizing in information systems research using focus groups." Australasian J ournal of Information Systems 17 (2).

Bentley, Kathleen A., Peter C. Brewer, and Tim V. Eaton. (2009). "Motivating Students to Prepare for Class and Engage in Discussion Using the Hot Seat." J ournal of Accounting Education 27 (3): 155-67. doi:10.1016/j.jaccedu.2010.07.001.

Blasco-Arcas, Lorena, Isabel Buil, Blanca Hernández-Ortega, and F. Javier Sese. (2013). "Using Clickers in Class. The Role of Interactivity, Active Collaborative Learning and Engagement in Learning Performance." Computers \& Education 62 (March): 102- 10. doi:10.1016/j.compedu.2012.10.019.

Blood, Erika and Richard Neel. (2008). “Using Student Response Systems in Lecture-Based Instruction: Does It Change Student Engagement and Learning?" J ournal of Technology and Teacher Education 16 (3): 375- 83.

Brickner, Daniel R., and Edwin R. Etter. (2008). "Strategies for Promoting Active Learning in a Principles of Accounting Course." Academy of Educational Leadership J ournal 12 (2): 87.

Brindley, Jane, Lisa Marie Blaschke, and Christine Walti. (2009). "Creating Effective Collaborative Learning Groups in an Online Environment." The International Review of Research in Open and Distributed Learning 10 (3). http:// www.irrodl.org/index.php/ irrodl/article/ view/ 675.

Brophy, J ere E. (2013). Motivating Students to Learn. Routledge.

Carnaghan, Carla, and Alan Webb. (2007). "Investigating the Effects of Group Response Systems on Student Satisfaction, Learning, and Engagement in Accounting Education." Issues in Accounting Education 22 (3): 391- 409. doi:10.2308/iace.2007.22.3.391.

Carroll, Judith, and Janette Ryan. (2007). Teaching International Students: Improving Learning for All. Routledge. 
Cavanagh, Michael. (2011). “Students' Experiences of Active Engagement through Cooperative Learning Activities in Lectures." Active Learning in Higher Education 12 (1): 23- 33. doi:10.1177/ 1469787410387724.

Chad, Paul. (2012). "The Use of Team-Based Learning as an Approach to Increased Engagement and Learning for Marketing Students: A Case Study." J ournal of Marketing Education, J uly, 0273475312450388. doi:10.1177/0273475312450388.

Chalmers, Denise, and Simone Volet. (1997). "Common Misconceptions about Students from South-East Asia Studying in Australia." Higher Education Research \& Development 16 (1): 87-99. doi:10.1080/0729436970160107.

Cherney, Isabelle D. (2008). 'The Effects of Active Learning on Students' Memories for Course Content." Active Learning in Higher Education 9 (2): 152- 71. doi:10.1177/ 1469787408090841.

Chu, Ling, and Theresa Libby. (2010). “Writing Mini-Cases: An Active Learning Assignment.” Issues in Accounting Education 25 (2): 245- 65. doi:10.2308/iace.2010.25.2.245.

Cooperstein, Susan E., and Elizabeth Kocevar-Weidinger. (2004). "Beyond Active Learning: A Constructivist Approach to Learning.” Reference Services Review 32 (2): 141- 48. doi:10.1108/00907320410537658.

Córdoba, J osé-Rodrigo, and Andriani Piki. (2012). "Facilitating Project Management Education through Groups as Systems." International J ournal of Project Management 30 (1): 83- 93. doi:10.1016/j.ijproman.2011.02.011.

Doubleday, Alison, Blase Brown, Philip Patston, Pamela J urgens-Toepke, Meaghan Strotman, Anne Koerber, Colin Haley, Charlotte Briggs, and G. Knight. (2015). "Social Constructivism and Case-Writing for an Integrated Curriculum." Interdisciplinary J ournal of Problem-Based Learning 9 (1). doi:10.7771/ 1541-5015.1502.

Douglass, J ohn, and Richard Edelstein. (2015). “The Global Market for International Students: American Perspectives.” International Higher Education 0 (59). https:/ / ejournals.bc.edu/ ojs/index.php/ihe/ article/ view/ 8482.

Duanmu, J ing-Lin, Gang Li, and Wei Chen. (2009). “Determinants of International Students' Academic Performance: A Comparison Between Chinese and Other International Students." Journal of Studies in International Education, May. doi:10.1177/ 1028315309331490.

Dunne, Ciarán. (2009). 'Host Students' Perspectives of Intercultural Contact in an Irish University." Journal of Studies in International Education, January. doi:10.1177/ 1028315308329787.

Eames, Chris, and Kevin Stewart. (2008). "Personal and Relationship Dimensions of Higher Education Science and Engineering Learning Communities." Research in Science \& Technological Education 26 (3): 311- 21. doi:10.1080/ 02635140802276686.

Edmonds, Christopher T., and Thomas P. Edmonds. (2008). "An Empirical Investigation of the Effects of SRS Technology on Introductory Managerial Accounting Students." Issues in Accounting Education 23 (3): 421- 34.

Eisenchlas, Susana, and Sue Trevaskes. (2007). "Developing Intercultural Communication Skills through Intergroup Interaction." Intercultural Education 18 (5): 413- 25. doi:10.1080/14675980701685271.

Elliott, CaroleJ ane, and Michael Reynolds. (2014). “Participative Pedagogies, Group Work and the International Classroom: An Account of Students' and Tutors' Experiences." Studies in Higher Education 39 (2): 307-20. doi:10.1080/ 03075079.2012.709492. 
Ellis, L., E. A. Cummings, and P. Turner. (2009). “Engaging International Students through PBL.” In Proceedings of the 2nd International Research Symposium on PBL '09, 1:EJ . http:/ / ecite.utas.edu.au/61489.

Eyvindson, Kyle, Annika Kangas, Teppo Hujala, and Pekka Leskinen. (2014). “Likert versus QApproaches in Survey Methodologies: Discrepancies in Results with Same Respondents." Quality \& Quantity 49 (2): 509-22. doi:10.1007/s11135-014-0006-y.

Fink, L. Dee. (2013). Creating Significant Learning Experiences: An Integrated Approach to Designing College Courses. J ohn Wiley \& Sons.

Flick, Uwe. (2008). Designing qualitative research. Sage.

Fowler, Lou. (2006). "Active Learning: An Empirical Study of the Use of Simulation Games in the Introductory Financial Accounting Class." Academy of Educational Leadership J ournal 10 (3): 93.

Guo, Shibao, and MackieChase. (2011). "Internationalisation of Higher Education: Integrating International Students into Canadian Academic Environment." Teaching in Higher Education 16 (3): 305- 18. doi:10.1080/ 13562517.2010.546524.

Haar, J ean, Gretchen Hall, Paul Schoepp, and David H. Smith. (2002). "How Teachers Teach to Students with Different Learning Styles." The Clearing House: A Journal of Educational Strategies, Issues and Ideas 75 (3): 142-45. doi:10.1080/00098650209599254.

Hall, Richard H, Harvest L Collier, Marcie L Thomas, and Michael G Hilgers. (2005). “A Student Response System for Increasing Engagement, Motivation, and Learning in High Enrollment Lectures - Viewcontent.cgi." In AMCIS 2005 Proceedings. http:/ / aisel.aisnet.org.simsrad.net.ocs.mq.edu.au/ cgi/ viewcontent.cgi?article=1787\&co ntext=amcis2005.

Halttunen, Kai, and Kalervo Järvelin. (2005). "Assessing Learning Outcomes in Two Information Retrieval Learning Environments." Information Processing \& Management 41(4): 949- 72. doi:10.1016/j.ipm.2004.02.004.

Hawthorne, Lesleyanne, I. Harry Minas, and Bruce Singh. (2004). "A Case Study in the Globalization of Medical Education: Assisting Overseas-Born Students at the University of Melbourne." Medical Teacher 26 (2): 150-59. doi:10.1080/ 0142159032000150539.

Hsieh, Min-Hua. (2007). “Challenges for International Students in Higher Education: One Student's Narrated Story of Invisibility and Struggle." College Student J ournal 41 (2): 379- 91.

Huang, Ying. (2012). “Transitioning Challenges Faced by Chinese Graduate Students.” Adult Learning 23 (3): 138-47. doi:10.1177/ 1045159512452861.

Huijser, H, L Kimmins, and P Evans. (2008). "Peer Assisted Learning in Fleximode: Developing an Online Learning Community - Viewcontent.cgi." Journal of Peer Learning 1(7): 51-60.

Jackson, Jane. (2003). "Case-Based Learning and Reticence in a Bilingual Context: Perceptions of Business Students in Hong Kong." System 31: 457- 69.

Johnson, Jill M., Dennis N. Bristow, and Kenneth C. Schneider. (2011). “Did You Not Understand The Question Or Not? An Investigation Of Negatively Worded Questions In Survey Research." Journal of Applied Business Research (JABR) 20 (1). http:// cluteinstitute.com/ ojs/index.php/J ABR/article/view/ 2197.

J ung, Insung, Seonghee Choi, Cheolil Lim, and J unghoon Leem. (2002). "Effects of Different Types of Interaction on Learning Achievement, Satisfaction and Participation in WebBased Instruction." Innovations in Education and Teaching International 39 (2): 15362. doi:10.1080/ 14703290252934603. 
Kelly, Philip, and Yvonne Moogan. (2012). "Culture shock and higher education performance: implications for teaching." Higher Education Quarterly 66 (1) 24-46.

Kim, Hye Yeong. (2011). 'International Graduate Students' Difficulties: Graduate Classes as a Community of Practices." Teaching in Higher Education 16 (3): 281-92. doi:10.1080/ 13562517.2010.524922.

Lincoln, Douglas J . (2008). "Teaching with Clickers in the Large-Size Principles of Marketing Class." Marketing Education Review 18 (1): 39- 45.

Marrone, Mauricio, Taylor, Murray and Hammerle, Mara. (2016). "Who is active in active learning: a systematic literature review of business literature." Academy of Taiwan business management review, 12 (2), 63-73

Modell, Sven. (2005). "Triangulation between Case Study and Survey Methods in Management Accounting Research: An Assessment of Validity Implications." Management Accounting Research 16 (2): 231- 54. doi:10.1016/j.mar.2005.03.001.

Montgomery, Catherine. (2009). "A Decade of Internationalisation: Has It Influenced Students' Views of Cross-Cultural Group Work at University?" J ournal of Studies in International Education, J anuary. doi:10.1177/ 1028315308329790.

Murphy, A., Farley, H., Lane, M., Hafeez-Baig, A. and Carter, B. (2014). "Mobile learning anytime, anywhere: what are our students doing?" Australasian J ournal of Information Systems, 18(3).

Neri, Frank, and Simon Ville. (2008). "Social Capital Renewal and the Academic Performance of International Students in Australia." The J ournal of Socio-Economics 37 (4): 151538. doi:10.1016/j.socec.2007.03.010.

OECD. 2015. "Education at a Glance (2015): OECD Indicators." OECD Publishing. http:// dx.doi.org/ 10.1787/ eag-2015-en.

Oliver, Gary R., and Rodney Coyte. (2011). "Engendering Learning Engagement in a Diverse Cohort: A Reflection." Accounting Research Journal 24 (2): 195- 204. doi:10.1108/ 10309611111163727.

Opdecam, Evelien, and Patricia Everaert. (2012). "Improving Student Satisfaction in a FirstYear Undergraduate Accounting Course by Team Learning." Issues in Accounting Education 27 (1): 53- 82. doi:10.2308/ iace-10217.

Pohl, Alexander, Vera Gehlen-Baum, and François Bry. (2011). "Introducing Backstage - a Digital Backchannel for Large Class Lecturesnull." Interactive Technology and Smart Education 8 (3): 186- 200. doi:10.1108/ 17415651111165410.

Pratt, Michael G. (2008). "Fitting oval pegs into round holes tensions in evaluating and publishing qualitative research in top-tier North American journals." Organizational Research Methods 11 (3): 481-509.

. (2009). "From the editors: For the lack of a boilerplate: Tips on writing up (and reviewing) qualitative research." Academy of Management J ournal 52 (5): 856-862.

Prince, Michael. (2004). "Does Active Learning Work? A Review of the Research." http:// www.rlillo.educsalud.cl/Capac_Docente_BecadosAPS/ Metodologias/Aprendiza je\%20Activo\%20Prince_2004.pdf.

Pye, G., Holt, D., Salzman, S., Bellucci, E. and Lombardi, L. (2015). "Engaging diverse student audiences in contemporary blended learning environments in Australian higher business education: Implications for Design and Practice." Australasian J ournal of Information Systems, 19.

Reinig, Bruce A., Ira Horowitz, and Gerald E. Whittenburg. (2011). "The Effect of Team-Based Learning on Student Attitudes and Satisfaction." Decision Sciences Journal of Innovative Education 9 (1): 27-47. doi:10.1111/j.1540-4609.2010.00289.x. 
Richards, Deborah, and Mauricio Marrone. (2014). "Identifying the Education Needs of the Business Analyst: An Australian Study." Australasian J ournal of Information Systems 18.2.

Rienties, Bart, Núria Hernández Nanclares, Divya J indal-Snape, and Peter Alcott. (2012). "The Role of Cultural Background and Team Divisions in Developing Social Learning Relations in the Classroom." J ournal of Studies in International Education, November, 1028315312463826. doi:10.1177/ 1028315312463826.

Riley, J. and Ward, K., (2015). Passive Learning Methods in an Accounting Information Systems Course. Issues in Accounting Education.

Rovai, Alfred P., and Kirk T. Barnum. (2007). “On-Line Course Effectiveness: An Analysis of Student Interactions and Perceptions of Learning." International J ournal of E-Learning \&Distance Education 18 (1): 57- 73.

Rubin, Robert S. (2006). "The Academic J ournal Review Process as a Framework for Student Developmental Peer Feedback." J ournal of Management Education 30 (2): 378-98. doi:10.1177/ 1052562905277185.

Sandy Q. Qu, and J ohn Dumay. (2011). “The Qualitative Research Interviewnull.” Qualitative Research in Accounting \& Management 8 (3): 238-64. doi:10.1108/ 11766091111162070.

Savin-Baden, Maggi, and Claire Howell Major. (2004). Foundations of Problem-Based Learning. McGraw-Hill Education (UK).

Sawir, Erlenawati. (2005). "Language Difficulties of International Students in Australia: The Effects of Prior Learning Experience.” International Education J ournal 6 (5): 567- 80.

Sawir, Erlenawati, Simon Marginson, Ana Deumert, Chris Nyland, and Gaby Ramia. (2008). "Loneliness and International Students: An Australian Study." J ournal of Studies in International Education 12 (2): 148- 80. doi:10.1177/ 1028315307299699.

Schreiber, Lisa M., and Brielle Elise Valle. (2013). "Social Constructivist Teaching Strategies in the Small Group Classroom." Small Group Research, May, 1046496413488422. doi:10.1177/ 1046496413488422.

Smith, C. Veronica, and LeeAnn Cardaciotto. (2011). "Is Active Learninglike Broccoli? Student Perceptions of Active Learning in Large Lecture Classes.” J ournal of the Scholarship of Teaching \& Learning 11 (1): 53- 61.

Stacey, Elizabeth. (2007). “Collaborative Learning in an Online Environment.” International J ournal of E-Learning \& Distance Education 14 (2): 14- 33.

Strauss, Anselm, and Juliet Corbin. (1990). Basics of qualitative research. Vol. 15. Newbury Park, CA: Sage.

Tan, J ohn, Diane C. Satin, and Christopher W. K. Lubwama. (2013). "A Real-World Business Approach to Teaching M.B.A. Managerial Accounting: Motivation, Design, and Implementation." Issues in Accounting Education 28 (2): 375- 402. doi:10.2308/iace50393.

Taylor, J ennyfer Lawrence, J essica Tsimeris, XuanYing Zhu, Duncan Stevenson, and Tom Gedeon. (2015). "Observations from Teaching HCI to Chinese Students in Australia." In Proceedings of the ASEAN CHI Symposium'15, 31- 35. ASEAN CHI Symposium'15. New York, NY, USA: ACM. doi:10.1145/2776888.2780366.

Treloar, Carla, Natalie McCall, Isobel Rolfe, Sallie-Anne Pearson, Gail Garvey, and Andrew Heathcote. (2000). "Factors Affecting Progress of Australian and International Students in a Problem-Based Learning Medical Course." Medical Education 34 (9): 708- 15. doi:10.1046/j.1365-2923.2000.00625.x. 
Vygotsky, L. S. (1980). Mind in Society: The Development of Higher Psychological Processes. Harvard University Press.

Welsh, Elaine. (2002). “Dealing with Data: Using NVivo in the Qualitative Data Analysis Process." Forum Qualitative Sozialforschung / Forum: Qualitative Social Research 3 (2). http:// www.qualitative-research.net/ index.php/ fqs/ article/ view/ 865.

Wilson, Steffen, and Jonathan Gore. (2013). "An Attachment Model of University Connectedness." The Journal of Experimental Education 81 (2): 178-98. doi:10.1080/00220973.2012.699902.

Wong, J oseph Kee-Kuok. (2004). "Are the Learning Styles of Asian International Students Culturally or Contextually Based?” International Education J ournal 4 (4): 154- 66.

Woo, Younghee, and Thomas C. Reeves. (2007). "Meaningful Interaction in Web-Based Learning: A Social Constructivist Interpretation." The Internet and Higher Education, Special Section of the AERA Education and World Wide Web special Interest Group (EdWeb/SIG), 10 (1): 15-25. doi:10.1016/j.iheduc.2006.10.005.

Wu, Yun, and Chetan S. Sankar. (2013). "Impact of Hands-On Research Experience on Students' Learning in an Introductory Management Information System Course." Decision Sciences Journal of Innovative Education 11 (4): 335-58. doi:10.1111/ dsji.12017.

Yin, Robert K. (2013). Case Study Research: Design and Methods: Design and Methods. 5th ed. Thousand Oaks, California: SAGE Publications.

Copyright: (C) 2017 Marrone, Taylor \& Hammerle. This is an open-access article distributed under the terms of the Creative Commons Attribution-NonCommercial 3.0 Australia License, which permits non-commercial use, distribution, and reproduction in any medium, provided the original author and AJ IS are credited. 